\title{
Mini-Review \\ Distance learning for teaching in physical education
}

\author{
Regina Celia A. Silva ${ }^{1}$ (1), Vera Lucia de F. F. e Silva ${ }^{2}$ (1), André Pontes Silva ${ }^{3}$ \\ ${ }^{1}$ Universidade Estadual Paulista, UNESP, Guaratinguetá, SP, Brazil; \\ ${ }^{2}$ Universidade Estadual Paulista, UNESP, Rio Claro, SP, Brazil; \\ ${ }^{3}$ Centro Universitario Claretiano, CEUCLAR, Batatais, SP, Brazil
}

\begin{abstract}
Aims: The objective of this article is to show, by analyzing the curricula of the professional formation in Physical Education, that it is possible the formation of teachers in Distance Learning Physical Education courses since the act of reflecting before, during and after the pedagogical practice characterizes the quality of contemporary educational development. A qualitative research; the present study consists of an analysis of curricula and Professional Training of Distance Learning in Physical Education, subsidized in bibliographic research. As the traditional teaching model prioritizes the selection of the most skilled in the search for the hero athlete, the pedagogical proposal based on reflection is more interesting since not all students will be or wish to be athletes. In this way, distance learning for teaching in physical education seems to be an excellent educational strategy for our postmodern society.
\end{abstract}

Keywords: education, physical education, distance education, teachers formation, physical education professional.

\section{Introduction}

The first generation of Distance Education was formed in the period from 1728 to 1970 and was characterized by the use of postal correspondence and printed materials containing exercises and tasks ${ }^{1}$.

The highlight of the first generation of Distance Education occurred in the 1920s, due to the socio-political and economic context of the current capitalist industrial model at that time. Guarezi ${ }^{2}$ states that the industrial archetype established mass production for the mass market and, consequently, educational institutions served the needs of the system inserted in that context. But what would Distance Education be? It is the educational process in which most communication is mediated by technologies capable of overcoming the physical distance between students and teachers, promoting access to the same set of information used in face-to-face professional training s $^{3,4,5,6}$. Despite the current technological evolution, Distance Education is not recent, as previously mentioned. However, Information and Communications Technology (ICT) and Internet access consolidated Distance Education in the act of teaching and learning.

The formation of teachers for Distance Learning in Physical Education confronts an old discussion about the vision we have about the curricular structures present in the Physical Education Faculties. Thus, through this bibliographical research, we seek to analyze, reflect and provoke a different thinking about the teaching methods for physical education teachers in the University.

Before the 1990s, according to Darido ${ }^{7}$, the professional formation of Physical Education was done in an uncritical way and from the perspective of the know-how to teach. Betti ${ }^{8}$ proposes a curricular model based on reflective teaching, where the search is in a dialectical relationship between theory and practice.

Thus, we cannot persist in a model of teacher training that doesn't approximate what is studied to what is desired in the school. These two questions are key points for thinking about the real possibility of Distance Learning in Physical Education.

The relevance of this study is to stimulate a critical thinking about the transformations over the years of education and physical education and the overcoming of the technicist vision that still persists, compromising the thinking and the possibility of the Distance Education Degree Program in Physical Education?.

Through this review, we will be able to reflect and even rethink the already pre-established concepts regarding distance modality for undergraduate studies in physical education. This model has produced many discussions, as exposed by Neira ${ }^{28}$.

With regard to the knowledge of Physical Education, we found a relevant aspect for the efficiency of the program: it was possible to "deconstruct" old representations through the use of methodologies that included activities of problematization of reality, discussion and reflection of school life. We believe that such formatted proposals will lead to changes, by increasing the teacher's awareness of the technical-political dimension of his / her performance

\section{Methods}

The present article is structured by qualitative research. This method is applied to this proposal because it is an analysis of curricular structures of Distance Education Degree Program in Physical Education, characterizing a bibliographical research. The review of the Literature is the result of an investigation that aims to explain a problem based on theoretical references, that is, publications in articles, dissertations, theses and books ${ }^{10,11,12}$.

The study was subdivided into three moments: review and analysis of the different conceptions of curriculum in the formation of teachers of Physical Education, review on the issues of pedagogical practices in distance learning and, in the 
third moment, research of proposals that are related to the new conceptions for the training of teachers in physical education, which is Distance Education.

\section{Results}

Initially, for eugenic needs during the 18th and 19th centuries in Europe, through scientific works based on Medicine, Biology and Pedagogical Gymnastics, several researchers used the expression "Physical Education" to refer to moral and intellectual formation, to the maintenance of health and physical preparation for military purposes of the current population ${ }^{13,14}$.

As shown by Neto ${ }^{15}$, Physical Education appears in Brazilian territory when the first groups of colonists, immigrants, and military, in different parts of the country, began activities seeking leisure, body formation or discipline, using the functional movements of the body to perform such exercises. According to Impolcetto ${ }^{16}$, the Couto-Ferraz's Reform officially included Physical Education in Brazil in 1851 and, on September 1st, 1998, Law no. 9696/98 established Physical Education as a PROFESSION, becoming regulated by the Federal and Regional Councils of Physical Education (CONFEF and CREF, acronyms in Portuguese). Currently, Physical Education is inserted in the clinical, academic and school environment, and its curricular components are linked to Biological and Health Sciences ${ }^{17,18}$.

According to Nóvoa ${ }^{19}$, the State constituted teaching as a profession, moving away from the task and the responsibility of educating of the Church, that was of a literary, humanistic and priestly nature. Thus, educating passed from clergy teachers to lay teachers, from vocational and priesthood character to technical-professional character and from authoritarian and conservative conceptions to the ideas of the Enlightenment and the Liberalism of Democracy. In this context, the State became aware of the power of this education in the formation of its political representatives with the public power and education became utilitarian. Through the teachers, the State would ideologically legitimize itself in the process of social reproduction.

Even with all intentions through education, we cannot deny that there has always been a need to transmit to the younger generations the knowledge accumulated and built over time, first to ensure the survival of each society and then to meet the needs of these societies.

According to Brandão ${ }^{20}$, there is not a single model of education, there is not only an educating way and not also a specific place for education to happen.

Therefore, Distance Education is the educational process in which most communication is mediated by technologies capable to overcome the physical distance between students and teachers since there is not only one way of educating or a specific place; education presents itself in different ways for different people in certain societies.

According to the thinking of Neira and $\mathrm{Nunes}^{21}$, education is the production, reconstruction, and appropriation of a culture of a society, from the oldest to the most modern civilizations. Over time, education has suffered and will suffer from the various pedagogical tendencies, reflected in society and in the political and social period they are inserted.

For Sancho and Hernández ${ }^{22}$, the way of designing and putting into practice teaching is the great challenge for professionals in the use of ICTs when they discover these new tools since teachers have a fundamental role in determining what can be done with Information and Communication Technologies.

From the 80 s onwards, there were significant changes throughout Brazilian society in the sociopolitical and economic spheres and, consequently, there were new pedagogical proposals in Education and Physical Education. Teachers felt the need to break with traditions that lost meaning to society and, therefore, to Physical Education, which valued performance and the selection of the most skillful.

Several studies in the last two decades have raised issues related to the curriculum and to the formation of Physical Education teachers. One of these issues is related to the uncritical formation with emphasis on sports training, from the perspective of the "know how to do to teach", pointed out by Darido $^{7}$, another one, pointed out by $\mathrm{Betti}^{8}$, is the relationship between the Theory-Practice: "[...] these relations constitute the main axis of the problems and limitations that today affect the curricula of professional formation in PE".

Thus, it is necessary to return to the authors Darido ${ }^{7}$ and Betti ${ }^{8}$, who present two models of curricula for the understanding of vocational and curriculum formation, in order to reflect the professional formation of teachers in Distance Learning in Physical Education courses. For Darido ${ }^{7}$, the traditional curriculum privileges the professional formation from the experience, the know-how, especially by the formation of the sports modalities. This model is pointed out by $\mathrm{Betti}^{8}$, as Traditional-Sports with emphasis on the disciplines considered predominantly practical and practices based on execution and demonstration.

This proposal of the curriculum makes the separation between practice and theory, being theory the content presented in the classroom and practice the contents developed in the court, in the pool, and other sports areas. Actually, through these traditional and traditional-sports curriculum models, it is impracticable to think about and concretize the professional formation of Distance Learning in Physical Education. This sportive and traditional vision makes it impossible to achieve this modality at a distance since it requires the graduate to execute and demonstrate technical skills and physical abilities.

The other models of curricular proposals, in the attempt to break with these models, also quoting Darido ${ }^{7}$, called Scientific Curriculum, valorize scientific knowledge, derived from the mother sciences, scientific foundation and philosophical subjects. In addition, Betti $^{8}$ puts this model as a curriculum of Technicalscientific orientation, which valorizes theoretical subjects and opens space for the human sciences and for philosophy. The vision and the concept of practice have another proposal: "teaching to teach".

But, according to Betti, this scientific treatment does not take into account the behavioral, cultural and political realities of work practice, since we must understand the practice as a professional action in a given organizational context. For Betti ${ }^{8}$, the practice should be the focus of research and training. 
Studies and authors of teaching in many countries propose a new model of formation in which the common point among them is the formation based on the practice of REFLECTION about teaching. The result would be the formation of a professional that reflects BEFORE, DURING and AFTER the action of teaching; however, due to the lack of knowledge about the techniques and possibilities that Distance Education promotes, the education professionals themselves create resistance in this formation model. Perhaps this factor can explain the lack of commitment by part of the teachers reported by Santos $^{23}$ referring to "sport and education", or even what Maldonado and Limongelli ${ }^{24}$ called "the great confusion about how to operationalize and align objectives/contents with method/evaluation" to construct a good planning and successful class ${ }^{25}$.

\section{Discussion}

The traditional model of Physical Education teaching, as shown by Darido ${ }^{26}$, emphasizes the performance and selection of the most skilled, privileging the procedural dimension of the contents in search of the hero athlete, but it doesn't make sense to contemporary society, since not all students will be or wish to be athletes. According to Mazo and Goellner ${ }^{27}$, in the nineteenth century, Physical School Education was also linked to the eugenization of a race for military purposes, where the teacher/dictator disregarded students' previous knowledge and trampled students' aspirations, imposing what "really mattered". In any case, the school has as objective to form critical thinking and to lead the students along the path of knowledge and autonomy. The more skilled students, who have discovered a certain affinity for the modalities presented during the classes, will seek the suitable means for the high performance, those interested in militarism will also do so, while the other students will follow the path validated by individual interest.

Thus, the characteristics required for the students of Distance Education are in agreement with the reflection-based training model, since the Distance Education student is co-responsible for their learning process and must be more autonomous and independent in the search for knowledge. They should reflect critically on what to learn and how to learn to reach their goals. The processes of distance learning articulate the behavioral, cultural, and political realities of the work practice of the future professionals of Physical Education.

Therefore, as cited by Neira ${ }^{28}$, we cannot remain in a model of distance formation for teachers that separates what one studies from what one wants in the school context. Thus, we feel hopeful about the use of new ICTs in Distance Education for teacher training, especially if methodologies based on problem-situation debates are used.

We believe that through this training model we will be able to visualize the quality of distance learning for teaching in Physical Education since, according to the study carried out by $\mathrm{Neira}^{28}$, with this model of teaching, in which there is the use of methodologies that use the proposal of problematization of reality, discussion and reflection of teaching practice, it will be possible to "deconstruct" old representations and broaden students' perspectives on the technical-political dimensions of their future pedagogical practices. Through reflection and a dialectical relationship between theory and practice, according to $\mathrm{Betti}^{8}$, professional performance is directly linked to the field of Physical Education research. We agree with Dowbor ${ }^{29}$ and Betti $^{30}$ on the importance of scientific knowledge, thus emphasizing the seriousness of distance learning for teaching in Physical Education. Since the Distance Education student is stimulated to make use of the ICTs through researches and related subjects from the beginning of the academic formation, the autonomy of the professional of Physical Education with regard to the scientific speculation becomes part of the routine because the student also learns the technique of self-learning, something crucial for the teaching and learning process, and later, continuous professional updating ${ }^{31}$.

With great experience in teaching for more than fifty years and after observing different teaching and learning methods used in several countries, Piazzi ${ }^{32}$ states that one of the best strategies to increase human intelligence is to create the habit of reading. We point out that the author in question refers to intelligence not only in the scientific scenario but as a whole, that is, the fluency, collective memory and multiple intelligences of the human being ${ }^{33,34,35}$. Based on this assumption, it is observed that the Distance Learning Physical Education teacher formation is closely linked to the qualitative evolution of human cognition since the adept of Distance Education has to read as part of his daily activities.

As stated by $\mathrm{Tani}^{36}$ and Silva ${ }^{37}$, the Physical Education professional studies the Movement Body Culture and Human Movement Science - an aspect that is literally related to social needs in the field of health, education, culture, and leisure. Thus, the study of individuals' quality of life has become a prominent theme for contemporary society and Physical Education, as a profession, enables people to accompany / assist cognitive development to maintain health, from the school environment to the clinician, leading children, adolescents, adults, and the elderly on the path to good education and quality of life $\mathrm{e}^{38,36,39,37}$.

\section{Conclusions}

From the elaborated reflections about the formation of Physical Education teachers, there is a need to "deconstruct" strongly constituted representations about the methodology, objectives and contents of Physical Education to overcome the still technical and sportive view understood by individuals.

Another point that must be observed is the great resistance of education professionals regarding the training model and the modality of teaching presented in this work, thus the vision of the reflective curriculum, where practice and theory would walk so close that it would be difficult to disassociate them, it would be ideal for the professional training of future Physical Education professionals both in person and in distance learning, so that we would unite what is studied to what is desired in the school. In this way, Distance Learning for Physical Education teacher formation allows: to share experiences; expand multiple intelligences and collective memory; to increase the vocabulary from 
the great initiation to the reading; to experience asynchronous and synchronous collective exchanges. Consequently, the production and re-signification of new knowledge, making learning more meaningful in the virtual environment, since recognition of the profession and the quality of the training depending on the profile and competence of the student/graduate.

\section{References}

1. Carvalho B. Ensino a distância: limites e possibilidades na formação de professores. 2014; (1): 15-284

2. Guarezi RCM. Educação a distância sem segredos. Curitiba: Editoralbpex. 2009.

3. Keegan DJ. On Defining Distance Education. Distance Education. 1980; 1 (1):13-36.

4. Pierre P. Distance Learning in Physical Education. Quest. 1998; 50 (4): 56-344.

5. Mielke D. Effective Teaching in Distance Education. ERIC Digest. 1999; 1 (1):1-16.

6. Capeletti AM. Ensino a Distância. Revista Eletrônica Saberes da Educação. 2014; 5 (1): 30-45

7. Darido SC. Teoria, prática e reflexão na formação profissional em Educação Física. Motriz: J. Phys. Ed. 1995; 1 (2): 124-128.

8. Betti M, Betti-Rangel IC. Novas Perspectivas na Formação Profissional em Educação Física. Motriz: J. Phys. Ed.1996; 2 (1) 10-15.

9. Brod FAT, Rodrigues SC. O conversar como estratégia de formação contínua na tutoria da educação profissional a distância. Rev. Bras. Educ. 2016; 21 (66): 631-652.

10. Neves JL. Pesquisa Qualitativa-Características, usos e possibilidades. Caderno de Pesquisas em Administração, São Paulo. 1996; 1 (3): 1-5.

11. Vilela LO. Aplicação do PROKNOW-C para seleção de um portifólio bibliográfico e análise bibliométrica sobre avaliação de desempenho da gestão do conhecimento. Revista Gestão Industrial. 2012; 8 (1): 77-92.

12. Marinheiro CA, Sanches EL, Archanjo RM. Metodologia da pesquisa científica. Batatais: Claretiano, 2016.

13. Bracht V. Educação Física e aprendizagem social. Porto Alegre: Magister, ed. 2, 1997.

14. González FJ, Fensterseifer PE. Dicionário crítico de Educação Física. Ijuí: Unijuí, 2014.

15. Neto SS. Alegre AN, Hunger D, Pereira JM.A formação do profissional de Educação Física no Brasil: uma história sob a perspectiva da legislação federal no século XX. Rev. Bras. Ciênc. Esporte (Impr.). 2004; 25 (2): 113-128.

16. Impolcetto FM. Introdução à História e Teoria da Educação Física. Batatais: Claretiano, 2013.

17. Capes. Coordenação de Aperfeiçoamento de Pessoal de Nível Superior: Tabela de Áreas do Conhecimento. Disponível em: http://www.capes.gov.br/images/documentos/documentos_diversos_2017/TabelaAreasConhecimento_072012_atualizada_2017_ v2.pdf [Acessado em 12 de setembro de 2017].

18. CNPq - Conselho Nacional de Desenvolvimento Científico e Tecnológico. Tabela de Áreas do Conhecimento. Disponível em http://www.cnpq.br/documents/10157/186158/ TabeladeAreasdoConhecimento.pdf [Acessado em 12 de setembro de 2017.
19. Nóvoa A. (Coord.). Os professores e a sua formação. Lisboa: Dom Quixote, 1992.

20. Brandão CR. O que é Educação. 10 ed. São Paulo: Editora Brasiliense, 1993.

21. Neira MG, Nunes MLF. Educação Física Currículo e Cultura. São Paulo: Phorte, 2009.

22. Sancho JM, Hernández F. Tecnologias para Transformar a Educação. Porto Alegre: Artmed, 2006.

23. Santos MAGNO. esporte nas aulas de educação física no ensino médio: o discurso dos professores da rede pública da cidade de ourinhos (SP). São Paulo: USJT. 2007; 1(1): 7-129

24. Maldonado DT, Limongelli A. Sistematização das aulas de Educação Física das séries inicias do Ensino Fundamental. Coleção Pesquisa Em Educação Física. 2009; 8 (2): 221-226.

25. Benakouche T. Educação a distância $(\mathrm{EaD})$ : uma solução ou um problema?. SOCIUS. 2000; 1 (5) 2-23.

26. Darido SC. Caderno de Formação. Educação física na escola: conteúdos, suas dimensões e significados. UNESP. Prograd. Caderno de formação: formação de professores didática geral. São Paulo: Cultura Acadêmica. 2012; 2 (1): 51-75.

27. Mazo JZ, Goellner SV. Pensando a educação física humanista: conservadora ou emancipatória?.Florianopolis. Motrivivencia. 1993; 6 (4): 65-71.

28. Neira MG. Formação para Docência em Educação Física a Distância: um estudo de caso. Grupo de Pesquisa em educação Física Escolar. Faculdade de Educação da USP. Brasil, 2008. 13 (119): 1-10.

29. Dowbor L. Tecnologias do conhecimento: os desafios da educação. Petrópolis: Vozes, 2001.

30. Betti M. Educação física como prática científica e prática pedagógica: reflexões à luz da filosofia da ciência. RBEFE. 2005; 19 (3): 183-197.

31. Silva SAPS, Costa AP, Miranda MLJ, Silva DL, Vecchi RL, Velardi M. Análise da nova proposta curricular do curso de educação física da universidade São Judas Tadeu frente às diretrizes curriculares nacionais e CONFEF. Formação profissional em Educação Física: Estudos e Pesquisas. Rio Claro: Biblioética, 2006; 1 (1): 1-19.

32. Piazzi P. Aprendendo inteligência: manual de instruções do cérebro para alunos em geral. São Paulo: Aleph, $3^{\circ}$ ed., 2014.

33. Samuels SJ. Toward a Model of Reading Fluency. Newark DE: International Reading Association. 2006. 1 (1): 24-46.

34. Martins ME, SÁ CM. Ser leitor no século XXI: importância da compreensão na leitura para o exercício pleno de uma cidadania responsável e activa. Saber (e) Educar. Porto: ESE de Paula Frassinetti. 2008; 13 (1): 235-246.

35. Gardner, H. Frames of mind: The theory of multiple intelligences. Basic books, 2011.

36. Tani G. Avaliação das condições do ensino de graduação em Educação Física: garantia de uma formação de qualidade. Revista Mackenzie de Educação Física e Esporte. 2009; 6 (2): 55-70.

37. Silva AP, Silva RCA, Silva VLFF. Os principais aspectos do Transtorno do Desenvolvimento da Coordenação nas Atividades da Vida Diária de uma criança em fase de crescimento: um consenso científico. Batatais: Claretiano. 2017; 6 (1): $37-45$. 
38. Both J, Nascimento JV, Lemos CAF, Donegá AL, Ramos MHKP, Petroski EC, et al. Qualidade de vida no trabalho percebida por professores de Educação Física. Rev. bras. cineantropom. desempenho hum. (Online). 2006; 8 (2): 45-52.

39. Santos ALP, Simões AC. Educação física e qualidade de vida: reflexões e perspectivas. Saúde e Sociedade. 2012; 21 (1): 181-192.

\section{Corresponding author}

André Pontes Silva

Centro Universitario Claretiano, BR Batatais 14300-172, Brazil

Email: vozandrepontes@gmail.com

Manuscript received on March 6, 2018

Manuscript accepted on October 1, 2018

(C) (2)

Motriz. The Journal of Physical Education. UNESP. Rio Claro, SP, Brazil - eISSN: 1980-6574 - under a license Creative Commons - Version 4.0 